\title{
Stress and health risk behaviors among university students
}

\author{
Estresse e comportamentos de risco à saúde entre estudantes universitários \\ Estrés y comportamientos de riesgo para la salud entre estudiantes universitarios
}

Ellaine Santana de Oliveira'
ORCID: 0000-0002-6799-3647

Antonia Fabiana Rodrigues da Silva' ORCID: 0000-0002-2851-2767

Kadija Cristina Barbosa da Silva' ORCID: 0000-0001-6132-3186

Tatiana Victória Carneiro Moura' ORCID: 0000-0001-9214-6012

Açucena Leal de Araújo' ORCID: 0000-0002-0100-0147

Ana Roberta Vilarouca da Silva' ORCID: 0000-0001-5087-4310

'Universidade Federal do Piauí. Picos, Piauí, Brazil.

How to cite this article: Oliveira ES, Silva AFR, Silva KCB, Moura TVC, Araújo AL, Silva ARV. Stress and health risk behaviors among university students. Rev Bras Enferm. 2020;73(1):e20180035. doi: http://dx.doi.org/10.1590/0034-7167-2018-0035

Corresponding Author:

Ellaine Santana de Oliveira

E-mail: ellaineso_nutricao@hotmail.com

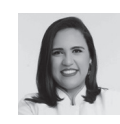

EDITOR IN CHIEF: Antonio José de Almeida Filho ASSOCIATE EDITOR: Fátima Helena Espírito Santo

Submission: 01-30-2018 Approval: 06-01-2018

\section{ABSTRACT}

Objective: To analyze the level of stress and its relationship with health risk behaviors among university students. Method: Cross-sectional analytical study carried out at a higher education institution in Picos-PI. A total of 377 students were evaluated for sociodemographic and academic variables, stress profile, sleep quality, alcohol use, smoking habits and level of physical activity. The Statistical Package for the Social Sciences (SPSS), version 20.0 was used for data processing and analysis. Results: Sleep quality was poor for $65.3 \%$ of the subjects, and sleep disturbances were found in $17.0 \%$. Stress was observed in $68.7 \%$ of the sample. Stress was associated with the following variables: gender, time in the institution, poor sleep quality. Conclusion: Most of the students evaluated present some level of stress associated with poor sleep quality, which is a risk to the quality of life of these individuals.

Descriptors: Stress; Psychological; Universities; Students; Sleep; Quality of Life.

\section{RESUMO}

Objetivo: Analisar o nível de estresse e sua relação com comportamentos de risco à saúde de estudantes universitários. Método: Estudo analítico do tipo transversal, realizado em uma instituição de ensino superior de Picos-PI. Participaram 377 estudantes, avaliados em características sociodemográficas e acadêmicas, perfil de estresse, qualidade do sono, consumo de álcool, tabagismo e nível de atividade física. Para processamento e análise dos dados, foi utilizado o software Statistical Package for the Social Sciences (SPSS), versão 20.0. Resultados: A qualidade do sono foi ruim para $65,3 \%$ dos indivíduos, sendo a presença de distúrbio do sono verificada em $17,0 \%$. O estresse foi observado em $68,7 \%$ da amostra. Demonstrou-se associação entre o estresse e as seguintes variáveis: sexo, tempo na instituição, má qualidade do sono. Conclusão: A maioria dos estudantes avaliados apresenta algum nível de estresse associado à má qualidade do sono, representando um risco à qualidade de vida desses indivíduos.

Descritores: Estresse Psicológico; Universidade; Estudantes; Sono; Qualidade de Vida.

\section{RESUMEN}

Objetivo: Analizar el nivel de estrés y su relación con los comportamientos de riesgo para la salud de estudiantes universitarios. Método: Estudio analítico de tipo transversal, realizado en una institución de enseñanza superior de Picos, Piauí. Participaron 377 estudiantes evaluados según características sociodemográficas y académicas, perfil de estrés, calidad del sueño, consumo de alcohol, tabaquismo y nivel de actividad física. Para procesar y analizar los datos, se utilizó el software Statistical Package for the Social Sciences (SPSS), versión 20.0. Resultados: La calidad del sueño estaba deteriorada en el 65,3\% de los individuos, ya que se comprobó la presencia de disturbio del sueño en el 17,0\%. El estrés se notó en el $68,7 \%$ de la muestra. Quedó demostrado que el estrés está asociado a las siguientes variables: sexo, tiempo en la institución, mala calidad del sueño. Conclusión: La mayoría de los estudiantes demostró algún nivel de estrés asociado a la mala calidad del sueño, lo que representa un riesgo para la calidad de vida de los mismos.

Descriptores: Estrés Sicológico; Universidad; Estudiantes; Sueño; Calidad de vida. 


\section{INTRODUCTION}

The university is a moment of intense changes in students' lives. It can be a source of stress and influence the student's adaptation, or lead to the acquisition of behavior patterns that will have repercussions throughout their lives ${ }^{(1-2)}$. These facts are concerning, since, according to Souza et al. ${ }^{(3)}$ and Faria, Gandolfi, Moura $^{(4)}$, the adoption of health risk behaviors is associated with a low level of psychological well-being among university students, due to the stress experienced in the university environment.

Studies have identified an association between high frequency of stress and health risk behaviors among university students ${ }^{(5)}$, with emphasis on the use of psychoactive substances ${ }^{(6-7)}$, sedentary behavior $^{(8)}$, inadequate sleep patterns ${ }^{(9)}$ and unhealthy eating habits ${ }^{(10)}$.

The university is an environment that produces knowledge in the most varied areas; however, being in the university does not always mean presenting a healthy lifestyle, a fact that is confirmed among students of several Higher Education Institutions (HEI) in Brazil ${ }^{(11-16)}$.

Therefore, student's health is a current issue that needs to be understood based on the interaction between the demands of Higher Education and the social, economic and personal factors, taking into consideration the vulnerability and psychic suffering of a significant number of university students ${ }^{(17)}$.

It is necessary to study the level of stress and the health risk behaviors among university students, since, as described by Moreira, Santiago and Alencar ${ }^{(18)}$, the early detection of risk factors can allow planning and implementing intervention programs.

\section{OBJECTIVE}

To analyze the level of stress and its relationship with health risk behaviors among university students.

\section{METHOD}

\section{Ethical aspects}

The present study was performed after obtaining approval from the Research Ethics Committee of the Federal University of Piauí (CEP/UFPI), according to Resolution 466/2012 of the National Health Council (CNS).

\section{Design, area and period}

Analytical, cross-sectional, quantitative study carried out from April to November 2016, in a higher education institution in the city of Picos-PI.

\section{Inclusion and exclusion criteria and sample}

The study participants were students of both genders between 18 and 30 years old. Students in long-distance learning or postgraduate education, those in a different academic calendar and exchange students were excluded.

A total of 377 undergraduate students from the areas of health, biological sciences, humanities, and exact sciences were selected proportionally among all the periods in each course.

\section{Study protocol}

The students' socio-demographic and academic characteristics were assessed through a semi structured form, with questions related to the year of admission to university, course, current period, gender, age, among others. The Brazilian Economic Classification Criteria (CCEB) were used to determine the socioeconomic level of the university students ${ }^{(19)}$.

The Lipp's Stress Symptoms Inventory (LSSI) was used to evaluate stress among university students. It is based on a quadriphasic model described by Lipp (alert, resistance, near exhaustion and exhaustion). In this stage, a specific professional from the area of psychology was assigned to evaluate the inventories.

The LSSI is divided in three phases or parts. The first one consists of 15 symptoms, divided into F1 (physical symptoms) and P1 (psychological symptoms). Symptoms that were experienced in the last 24 hours should be marked with an $x$. The cut-off score in this part is six. The second phase also consists of 15 symptoms, equally divided into F2 (physical symptoms) and P2 (psychological symptoms). In this phase, the symptoms experienced in the last week should be marked and the cut-off score is three. The third phase is composed of 23 symptoms, also divided into F3 (physical symptoms) and P3 (psychological symptoms). The symptoms experienced in the last month should be marked and the cut-off score is eight. The correction tables present in the ISSL Handbook ${ }^{(20)}$ were used to identify the phase of stress that the individual was experiencing.

Sleep quality was analyzed trough the Pittsburgh Sleep Quality Index (PSQI), in the version validated, translated and adapted to the Brazilian standards. The sum of the scores in this index (zero to three points for each component) produces a global score, which ranges from 0 to 21, with highest score indicating the worst quality of sleep. University students who present scores above five points will be classified as poor sleepers ${ }^{(21)}$.

The Alcohol Use Disorder Identification Test was used to identify individuals at risk and with probable alcohol dependence. It is a self-administered, low-cost test that evaluates alcohol consumption in the last twelve months. The total score ranges from 0 to 40 points. Thus, four categories of alcohol consumption are defined: low risk (0 to 7 points), risk (8 to 15 points), harmful drinking (16 to 19 points) and probable alcohol dependence ( $\geq 20$ points) ${ }^{(22)}$.

Regarding smoking habits, the students were asked about the frequency of cigarette smoking, and were classified into four categories: daily smokers, occasional smokers, ex-smokers and non-smokers. The students considered as daily smokers were those who smoked at least one cigarette per day on the month prior to application of the questionnaire; occasional smokers were those who did not smoke everyday; ex-smokers were those who had quit smoking for at least one month; and non-smokers were those who had never smoked or had been smoking for less than one month ${ }^{(23)}$.

The International Physical Activity Questionnaire version 8 (IPAQ-8), a short form validated in Brazil ${ }^{(24)}$, was used to assess the level of physical activity. It assesses the number of days and minutes of physical activities performed as leisure, work, transportation and housework in the week prior to completing the questionnaire. With these data, the IPAQ classifies the individual into the categories: Sedentary, Insufficiently active A, Insufficiently active $B$, Active and very active. 


\section{Analysis of results and statistics}

The Statistical Package for the Social Sciences (SPSS), version 20.0 was used for data processing and analysis.

\section{RESULTS}

Most of the participants were female (61.5\%), between 18 and 21 years old (61.5\%), with a median of 21 years (interquartile range: $19-22.5$ years), self-identified as brown (54.6\%) and were single (92.8\%). In addition, the majority had family incomes in the range of 1 to 3 minimum wages (68.4\%), belonged to the socioeconomic classes $\mathrm{C} 1$ and C2 (53.6\%), lived with relatives (57.0\%) and were from other cities of Piauí (53.3\%) (Table 1).

Table 1 - Characterization of university students regarding socioeconomic data, Picos, Piauí, Brazil, 2016

\begin{tabular}{|c|c|c|c|}
\hline Variables & $\mathbf{n}$ & $\%$ & Median (P25-P75) \\
\hline \multicolumn{4}{|l|}{ Gender } \\
\hline Male & 145 & 38.5 & \\
\hline Female & 232 & 61.5 & \\
\hline Age & & & $21.0(19.0-22.5)$ \\
\hline 18-21 years & 232 & 61.5 & \\
\hline $22-25$ years & 104 & 27.5 & \\
\hline$>25$ years & 41 & 10.9 & \\
\hline \multicolumn{4}{|l|}{ Skin color or race/ethnicity } \\
\hline White & 122 & 32.4 & \\
\hline Brown & 206 & 54.6 & \\
\hline Black & 42 & 11.1 & \\
\hline Yellow & 06 & 1.6 & \\
\hline Indigene & 01 & 0.3 & \\
\hline \multicolumn{4}{|l|}{ Civil status } \\
\hline Married & 14 & 3.7 & \\
\hline Domestic partnership & 06 & 1.6 & \\
\hline Single & 350 & 92.8 & \\
\hline Others & 07 & 1.9 & \\
\hline Family income $e^{* *}$ & & & $1200.00(880.00-2000.00)$ \\
\hline$<1$ minimum wages & 67 & 17.8 & \\
\hline $1-3$ minimum wages & 258 & 68.4 & \\
\hline$>3$ minimum wages & 52 & 13.8 & \\
\hline \multicolumn{4}{|l|}{ Socioeconomic level } \\
\hline $\mathrm{A} 1-\mathrm{A} 2$ & 06 & 1.6 & \\
\hline B1-B2 & 92 & 24.4 & \\
\hline $\mathrm{C} 1-\mathrm{C} 2$ & 202 & 53.6 & \\
\hline$D-E$ & 77 & 20.4 & \\
\hline \multicolumn{4}{|l|}{ Current living situation } \\
\hline Alone & 18 & 4.8 & \\
\hline With relatives & 215 & 57.0 & \\
\hline With friends & 144 & 38.2 & \\
\hline \multicolumn{4}{|l|}{ City of origin } \\
\hline Picos - PI & 128 & 34.0 & \\
\hline Other cities in Piauí & 201 & 53.3 & \\
\hline Other cities in the Northeast region & 39 & 10.3 & \\
\hline Cities in other regions & 09 & 2.4 & \\
\hline
\end{tabular}

Note: * P25 - P75: interquartile range; ** Classification calculated based on the Brazilian monthly minimum wage effective in 2016: $R \$ 880.00$.

Regarding health risk behaviors, $93.1 \%$ of college students reported being non-smokers. As for alcohol use, 78.5\% were classified as low risk. Regarding the level of physical activity, $47.5 \%$ were active, while $30.8 \%$ were insufficiently active. The analysis of sleep quality showed that $65.3 \%$ of the participants were poor sleepers and $17.0 \%$ had sleep disturbances (Table 2).

Table 2 - Characterization of variables related to health risk behaviors, Picos, Piauí, Brazil, 2016

\begin{tabular}{lcc}
\hline \multicolumn{1}{c}{ Variables } & $\mathbf{n}$ & $\%$ \\
\hline Smoking & & \\
Daily smoker & 07 & 1.9 \\
Occasional smoker & 18 & 4.8 \\
Ex smoker & 01 & 0.3 \\
Non-smoker & 351 & 93.1 \\
Alcohol use & & \\
Low risk & 296 & 78.5 \\
Risk & 58 & 15.4 \\
Harmful drinking & 14 & 3.7 \\
Probable dependence & 09 & 2.4 \\
Level of physical activity & & \\
Sedentary & & \\
Insufficiently active & 41 & 10.9 \\
Active & 116 & 30.8 \\
Very active & 179 & 47.5 \\
Sleep quality & 41 & 10.9 \\
Good & & \\
Poor & 64 & 17.8 \\
Sleep disturbance & 246 & 65.3 \\
\hline
\end{tabular}

The levels of stress were compared with the socioeconomic and demographic data. The phases of stress were associated with gender $(p=0.000)$ and time in the teaching institution $(p=0.031)$ (Table 3$)$.

Among the health risk behaviors studied, the sleep quality was the only one that presented a moderate association with the stress phases $(p=0.000)$, indicating that most university students with stress have poor sleep quality or sleep disturbances (Table 4).

\section{DISCUSSION}

The characterization of higher education students presented here is similar to other national and international studies, which show majority of female students, single, with family income between 1 and 3 minimum wages, belonging to socioeconomic levels $C 1$ and C2, and between 18 and 21 years old (1,5,25-28).

Corroborating the findings of this study in relation to the risk behaviors among university students, the literature has reported low levels of smoking among Brazilian youth ${ }^{(7,29-30)}$ and among the general population ${ }^{(31)}$. The low prevalence of smoking can be a reflection of anti-smoking policies implemented in the country. This is a positive aspect, since smoking is one of the most important risk factors for the occurrence of chronic noncommunicable diseases ${ }^{(32)}$.

Regarding alcohol, most of the young students evaluated were classified as low risk; however, the fact that some university students experienced harmful drinking or characteristics of probable alcohol dependence in the prior month is alarming. According to Soares and Oliveira ${ }^{(7)}$, alcohol use tends to persist throughout the university years, and may even remain long enough to harm 
Table 3 - Stratification of the level of stress with socioeconomic and academic data, Picos, Piauí, Brazil, 2016

\begin{tabular}{|c|c|c|c|c|c|c|c|c|c|c|c|}
\hline \multirow{3}{*}{ Variables } & \multicolumn{10}{|c|}{ Level of stress } & \multirow{3}{*}{$\underset{\text { value* }}{p}$} \\
\hline & \multicolumn{2}{|c|}{ No stress } & \multicolumn{2}{|c|}{ Alert } & \multicolumn{2}{|c|}{ Resistance } & \multicolumn{2}{|c|}{ Near exhaustion } & \multicolumn{2}{|c|}{ Exhaustion } & \\
\hline & $\mathbf{n}$ & $\%$ & $\mathbf{n}$ & $\%$ & $n$ & $\%$ & $\mathbf{n}$ & $\%$ & $\mathbf{n}$ & $\%$ & \\
\hline Gender & & & & & & & & & & & 0.000 \\
\hline Male & 73 & 61.9 & 02 & 40.0 & 59 & 28.9 & 09 & 20.9 & 02 & 28.6 & \\
\hline Female & 45 & 38.1 & 03 & 60.0 & 145 & 71.1 & 34 & 79.1 & 05 & 71.4 & \\
\hline Age & & & & & & & & & & & 0.154 \\
\hline 18-21 years & 75 & 63.6 & 02 & 40.0 & 131 & 64.2 & 20 & 46.5 & 04 & 57.1 & \\
\hline $22-25$ years & 27 & 22.9 & 03 & 60.0 & 55 & 27.0 & 16 & 37.2 & 03 & 42.9 & \\
\hline$>25$ years & 16 & 13.6 & - & - & 18 & 8.8 & 07 & 16.3 & - & - & \\
\hline Family income & & & & & & & & & & & 0.168 \\
\hline$<1$ wage & 19 & 16.1 & 03 & 60.0 & 35 & 17.2 & 09 & 20.9 & 01 & 14.3 & \\
\hline $1-3$ wages & 89 & 75.4 & 02 & 40.0 & 135 & 66.2 & 28 & 65.1 & 04 & 57.1 & \\
\hline$>3$ wages & 10 & 8.5 & - & - & 34 & 16.7 & 06 & 14.0 & 02 & 28.6 & \\
\hline City of origin & & & & & & & & & & & 0.976 \\
\hline $\mathrm{Picos}-\mathrm{PI}$ & 40 & 33.9 & 01 & 20.0 & 71 & 34.8 & 14 & 32.6 & 02 & 28.6 & \\
\hline Other cities in Piauí & 61 & 51.7 & 03 & 60.0 & 109 & 53.4 & 25 & 58.1 & 03 & 42.9 & \\
\hline Other cities in the Northeast region & 14 & 11.9 & 01 & 20.0 & 19 & 9.3 & 03 & 7.0 & 02 & 28.6 & \\
\hline Cities in other regions & 03 & 2.5 & - & - & 05 & 2.5 & 01 & 2.3 & - & - & \\
\hline Area of study & & & & & & & & & & & 0.054 \\
\hline Health and biological sciences & 41 & 34.7 & 01 & 20.0 & 90 & 44.1 & 18 & 41.9 & 03 & 42.9 & \\
\hline Humanities & 21 & 17.8 & 01 & 20.0 & 51 & 25.0 & 14 & 32.6 & 03 & 42.9 & \\
\hline Exact sciences & 56 & 47.5 & 03 & 60.0 & 63 & 30.9 & 11 & 25.6 & 01 & 14.3 & \\
\hline Time in the institution & & & & & & & & & & & 0.031 \\
\hline $1-12$ months & 38 & 32.2 & 02 & 40.0 & 33 & 16.2 & 05 & 11.6 & 03 & 42.9 & \\
\hline 13-24 months & 21 & 17.8 & 01 & 20.0 & 63 & 30.9 & 09 & 20.9 & 03 & 42.9 & \\
\hline 25-36 months & 26 & 22.0 & 01 & 20.0 & 46 & 22.5 & 11 & 25.6 & - & - & \\
\hline $37-48$ months & 26 & 22.0 & 01 & 20.0 & 39 & 19.1 & 10 & 23.3 & - & - & \\
\hline $49-60$ months & 07 & 5.9 & - & - & 21 & 10.3 & 07 & 16.3 & 01 & 14.3 & \\
\hline$>60$ months & - & - & - & - & 02 & 1.0 & 01 & 2.3 & - & - & \\
\hline
\end{tabular}

Table 4 - Association of level of stress with variables related to health risk behaviors, Picos, Piauí, Brazil, 2016

\begin{tabular}{|c|c|c|c|c|c|c|c|c|c|c|c|}
\hline \multirow{3}{*}{ Variables } & \multicolumn{10}{|c|}{ Level of stress } & \multirow{3}{*}{$\underset{\text { value }^{*}}{p}$} \\
\hline & \multicolumn{2}{|c|}{ No stress } & \multicolumn{2}{|c|}{ Alert } & \multicolumn{2}{|c|}{ Resistance } & \multicolumn{2}{|c|}{ Near exhaustion } & \multicolumn{2}{|c|}{ Exhaustion } & \\
\hline & $\mathbf{n}$ & $\%$ & $\mathbf{n}$ & $\%$ & $\mathbf{n}$ & $\%$ & $\mathbf{n}$ & $\%$ & $\mathbf{n}$ & $\%$ & \\
\hline Smoking & & & & & & & & & & & 0.583 \\
\hline Daily smoker & - & - & - & - & 05 & 2.5 & 02 & 4.7 & - & - & \\
\hline Occasional smoker & 07 & 5.9 & - & - & 09 & 4.4 & 02 & 4.7 & - & - & \\
\hline Ex smoker & 1 & 0.8 & - & - & - & - & - & - & - & - & \\
\hline Non-smoker & 110 & 93.2 & 05 & 100.0 & 190 & 93.1 & 39 & 90.7 & 07 & 100.0 & \\
\hline Alcohol use & & & & & & & & & & & 0.675 \\
\hline Low risk & 101 & 85.6 & 04 & 80.0 & 155 & 76.0 & 31 & 72.1 & 05 & 71.4 & \\
\hline Risk & 13 & 11.0 & 01 & 20.0 & 34 & 16.7 & 08 & 18.6 & 02 & 28.6 & \\
\hline Harmful drinking & 03 & 2.5 & - & - & 08 & 3.9 & 03 & 7.0 & - & - & \\
\hline Probable dependence & 01 & 0.8 & - & - & 7 & 3.4 & 1 & 2.3 & - & - & \\
\hline Level of physical activity & & & & & & & & & & & 0.072 \\
\hline Sedentary & 10 & 8.5 & - & - & 26 & 12.7 & 05 & 11.6 & - & - & \\
\hline Insufficiently active & 31 & 26.3 & 01 & 20.0 & 70 & 34.3 & 14 & 32.6 & - & - & \\
\hline Active & 57 & 48.3 & 04 & 80.0 & 91 & 44.6 & 21 & 48.8 & 06 & 85.7 & \\
\hline Very active & 20 & 16.9 & - & - & 17 & 8.3 & 03 & 7.0 & 01 & 14.3 & \\
\hline Sleep quality & & & & & & & & & & & $0.000^{* *}$ \\
\hline Good & 38 & 32.2 & - & - & 26 & 12.7 & 01 & 2.3 & 02 & 28.6 & \\
\hline Poor & 74 & 62.7 & 03 & 60.0 & 141 & 69.1 & 25 & 58.1 & 03 & 42.9 & \\
\hline Sleep Disturbance & 06 & 5.1 & 02 & 40.0 & 37 & 18.1 & 17 & 39.5 & 02 & 28.6 & \\
\hline
\end{tabular}

Note: + Likelihood ratio. ${ }^{*}$ Cramer's V $=0.258, p=0.000$ : statistically significant moderate association between the variables level of stress and quality of sleep. 
the students' health, since alcohol is an important preventable risk factor for cardiovascular diseases (CVD) and it can contribute to the adoption of other health risk behaviors ${ }^{(33)}$.

The evaluation of sedentarism among the students showed a satisfactory level of physical activity in more than half of the sample. These findings differ from other studies involving university students, which found percentages of sedentarism ranging from $70.2 \%$ to $78.4 \%^{(1,14,26,29)}$. These results can be explained by the widespread dissemination of the importance of taking care of the body and the negative effects of lack of physical exercise. However, the insufficient level of physical activity identified in part of the sample suggests that there is still resistance to physical exercise in the daily life of many university students, who, in general, claim they have excessive activities, fatigue, lack of time or lack of motivation ${ }^{(34)}$.

The results related to sleep quality reveal a critical scenario, since sleep has an important role in the physical, psychological and mental health of individuals, and poor sleep can lead to serious cognitive problems ${ }^{(9,25,30,35-40)}$. Despite the different socioeconomic and cultural characteristics, studies from different parts of the world also found poor sleep quality among undergraduate students, which is explained by short sleep duration and later bedtimes on weekdays due to their high demand of activities, associated with changes in sleep patterns on weekends ${ }^{(41-42)}$.

Among other possible explanations for the high number of individuals with poor sleep quality, it is worth mentioning that the daily life in the $\mathrm{HEl}$ is characterized by numerous academic activities that may lead to the reduction of hours of sleep. It is also worth noting that many students end up having an unbalanced lifestyle, replacing hours of sleep with social interaction, sometimes associated with alcohol and tobacco use $\mathrm{e}^{(37,40)}$.

For decades, the literature has been demonstrating the importance of assessing the vulnerability to stress among young adults. The transitions experienced in this phase lead to confrontation of new situations, such as searches for careers, autonomy, stability, affective relationship, identities and for the role that this young person will have in society, increasing their susceptibility to stressors ${ }^{(43)}$.

In this aspect, stress was present in the majority of the university students investigated, which is in consonance with other investigations ${ }^{(44-45)}$. The most frequent phase among the students was resistance, a finding similar to those of Lameu, Salazar and Souza ${ }^{(46)}$ and Bonifácio et al. ${ }^{(17)}$. Although few students reached more severe phases of stress, the detection of these less severe stages also require attention ${ }^{(44)}$, since less intense but recurrent stress events are potentially pathogenic ${ }^{(20)}$.

Female students did not only present a higher percentage of stress, but also showed a higher prevalence in all phases, results also verified in other studies ${ }^{(45-46)}$. Considering that the stress factors faced in the university are the same for men and women, a possible explanation for this result may be that women have less difficulty to express their fears, discomforts and difficulties.

The time in the institution was another variable significantly associated with stress levels. According to Soares and Oliveira ${ }^{(7)}$ after admission to the university comes a phase of adaptation to the daily life of higher education and the new teaching methodologies. It is known that every process in which the subject is exposed to new situations and needs to develop or acquire skills can lead to some intensity of stress. Therefore, the relationship between these variables in the university context was predictable.

Sleep quality moderately influenced the stress profile of university students $(p=0.000)$, as the majority of individuals with poor sleep quality were in the most severe stages of stress. In this sense, Sateia ${ }^{(47)}$ explains that the association between psychological illness and distress and sleep disorders is bidirectional, that is, mental disorders lead to the occurrence of sleep disorders and vice-versa.

\section{Limitations of the study}

The quantitative evaluation is highlighted as a limitation of this study, as the predictors of stress and the occurrence of risk behaviors were not evaluated. These data could favor a clearer profile about the main demands and stressors for university students.

\section{Contributions to nursing, health, or public policy}

Despite the limitations, the results reached the objective proposed and contribute to the health of university students by providing important information for the development of other studies in the same perspective and for the construction of educational strategies focused on the ways of coping with stress and choosing healthier life behaviors, which can have positive impacts on quality of life and health in general.

\section{CONCLUSION}

This study demonstrated that most university students present some level of stress which is associated with the variables: gender, time in the institution and sleep quality.

Therefore, the presence of stress is a risk to the physical and mental health of university students and can directly interfere with their growth and personal and professional development, producing negative effects that influence their daily living habits and their health.

It is emphasized that this subject needs to be further debated in the university environment, since stress is a current public health problem that affects the entire academic community, and the university cannot remain silent in this scenario. Thus, it is necessary to develop integrated actions that help students to face stressful experiences in a conscious and healthy way.

\section{REFERENCES}

1. Lima ACS, Araújo MFM, Freitas RWJF, Zanetti ML, Almeida PC, Damasceno MMC. Risk factors for Type 2 Diabetes Mellitus in college students: association with sociodemographic variables. Rev Latino-Am Enfermagem. 2014;22(3):484-90. doi: 10.1590/0104-1169.3053.2441 
2. Savegnago Mialich M, Covolo N, Cheli Vettori J, Jordao Junior AA. Relationship between body composition and level of physical activity among university students. Rev Chil Nutr. 2014;41(1):46-53. doi: 10.4067/S0717-75182014000100006

3. Souza LDM, Maragalhoni TC, Quincoses MT, Jansen K, Cruzeiro ALS, Ores L, et al. Bem-estar psicológico de jovens de 18 a 24 anos: fatores associados. Cad Saúde Pública. 2012;28(6):1167-74. Doi: 10.1590/S0102-311X2012000600015

4. Faria YO, Gandolfi L, Moura LBA. Prevalence of risk behaviors in young university students. Acta Paul Enferm. 2014;27(6):591-5. doi: $10.1590 / 1982-0194201400096$

5. Barbosa RR, Martins MCG, Carmo FPT, Jacques TM, Serpa RG, Calil OA, Barbosa LFM. Study on Lifestyles and Stress Levels in Medicine Students. Int J Cardiovasc Sci. 2015;28(4):313-9. doi: 10.5935/2359-4802.20150045

6. Carvalho PD, Barros MVG, Lima RA, Santos CM, Mélo EN. Condutas de risco à saúde e indicadores de estresse psicossocial em adolescentes estudantes do Ensino Médio. Cad Saúde Pública. 2011;27(11):2095-105. doi: 10.1590/S0102-311X2011001100003

7. Soares MH, Oliveira FS. The relation between alcohol, tobacco and stress in nursing students. SMAD, Rev. Eletrônica Saúde Mental Álcool Drog [Internet]. 2013[cited 2017 Jun 28];9(2):88-94. Available from: http://pepsic.bvsalud.org/pdf/smad/v9n2/07.pdf

8. Cruz SY, Fabián C, Pagán I, Rios JL, Gonzalez AM, Betancourt J, et al. Physical activity and its associations with sociodemographic characteristics, dietary patterns, and perceived academic stress in students attending college in Puerto Rico. P R Health Sci J [Internet]. 2013[cited 2017 Jun 28];32(1):44-50. Available from: https://www.slan.org.ve/publicaciones/completas/pdf/Physical-Activity-and-itsAssociations-with-Sociodemographic-Characteristics-Dietary-Patterns-and-Perceived-Academic-Stress.pdf

9. Benavente SBT, Silva RM, Higashi AB, Guido LA, Costa ALS. Influence of stress factors and sociodemographic characteristics on the sleep quality of nursing students. Rev Esc Enferm USP. 2014;48(3):512-8. doi: 10.1590/S0080-623420140000300018

10. Penaforte F, Matta N, Japur C. Associação entre estresse e comportamento alimentar em estudantes universitários. Demetra. 2016;11(1):22537. doi: $10.12957 /$ demetra.2016.18592

11. Gasparotto GS, Gasparotto LPR, Salles MR, Campos W. Fatores de risco cardiovascular em universitários: comparação entre sexos, períodos de graduação e áreas de estudo. Medicina (Ribeirão Preto, Online). 2013;46(2):154-63. doi: 10.11606/issn.2176-7262.v46i2p154-63

12. Gasparotto GS, Gasparotto LPR, Rossi LM, Moreira NB, Bontorin MS, Campos W. Association between moment of the undergraduate course and cardiovascular risk factors in university students. Rev Latino-Am. Enfermagem. 2013;21(3):687-94. doi: 10.1590/ S0104-11692013000300006

13. Morais CAS, Oliveira SHV, Brandão FC, Gomes IF, Lima LM. Fatores de risco cardiovascular em estudantes de graduação da Universidade Federal de Viçosa-MG. Rev Inst Ciênc Saúde [Internet]. 2011 [cited 2017 Jun 28];29(4):261-4. Available from: https://www.unip.br/presencial/ comunicacao/publicacoes/ics/edicoes/2011/04_out-dez/V29_n4_2011_p261-264.pdf

14. Santos JJA, Saracini N, Silva WC, Guilherme JH, Costa TA, Silva MRAG. Estilo de vida relacionado à saúde de estudantes universitários: comparação entre ingressantes e concluintes. ABCS Health Sci. 2014;39(1):17-23. doi: 10.7322/abcshs.v39i1.256

15. Santos LR, Brito ECC, Lira Neto JCG, Alves LEP, Alves LRA, Freitas RWJF. Analysis of sedentary lifestyle among college students. Rev Enferm UERJ [Internet]. 2014 [cited 2017 Jun 28];22(3):416-21. Available from: http://www.e-publicacoes.uerj.br/index.php/enfermagemuerj/ article/view/13768

16. Silva DAS, Pereira IMM, Almeida MB, Silva RJS, Oliveira ACC. Estilo de vida de acadêmicos de educação física de uma universidade pública do estado de Sergipe, Brasil. Rev Bras Ciênc Esporte. 2012;34(1):53-67. doi: 10.1590/S0101-32892012000100005

17. Bonifácio SP, Silva RCB, Montesano FT, Padovani RC. Investigação e manejo de eventos estressores entre estudantes de Psicologia. Rev Bras Ter Cogn [Internet]. 2011 [cited 2017 Jun 28];7(1):15-20. Available from: http://pepsic.bvsalud.org/scielo.php?script=sci_arttext\&pid $=$ S1808-56872011000100004

18. Moreira TMM, Santiago JCS, Alencar GP. Self-perceived health and clinical characteristics in young adult students from the Brazilian northeast. Rev Esc Enferm USP. 2014;48(5):793-802. doi: 10.1590/S0080-6234201400005000004

19. Associação Brasileira de Empresas de Pesquisa (ABEP). Critério de Classificação Econômica Brasil - 2014 [Internet]. São Paulo: ABEP; 2014 [cited 2016 Aug 20]. Available from: http://www.abep.org/codigosCondutas.aspx

20. Lipp MEN. Manual do inventário de sintomas de stress para adultos de Lipp (ISSL). São Paulo: Casa do Psicólogo; 2000.

21. Bertolazi AN, Fagondes SC, Hoff LS, Dartora EG, Miozzo ICS, Barba MEF, et al. Validation of the Brazilian Portuguese version of the Pittsburgh Sleep Quality Index. Sleep Med. 2011;12(1):70-5. doi: 10.1016/j.sleep.2010.04.020

22. Babor TF, Higgings-Biddle JC, Sauders JB, Monteiro MG. AUDIT: teste para identificação de problemas relacionados ao uso de álcool: roteiro para uso em atenção primária. Ribeirão Preto: Programa de Ações Integradas para Prevenção e Atenção ao Uso de Álcool e Drogas na Comunidade; 2003.

23. Ministério da Saúde (BR). Secretaria de Vigilância em Saúde. Secretaria de Gestão Estratégica e Participativa. Vigitel Brasil 2010: vigilância de fatores de risco e proteção para doenças crônicas por inquérito telefônico [Internet]. Brasília: Ministério da Saúde; 2011 [cited 2017 Jul 16]. Available from: http://bvsms.saude.gov.br/bvs/publicacoes/vigitel_2010.pdf

24. Matsudo S, Araújo T, Matsudo V, Andrade D, Andrade E, Oliveira LC, et al. Questionário Internacional de Atividade Física (IPAQ): estudo de validade e reprodutibilidade no Brasil. Rev Bras Ativ Fís Saúde. 2001;6(2):5-18. DOI: 10.12820/rbafs.v.6n2p5-18

25. Araújo MFM, Vasconcelos HCA, Marinho NBP, Freitas RWJF, Damasceno MMC. Níveis plasmáticos de cortisol em universitários com má qualidade de sono. Cad Saúde Colet. 2016;24(1):105-10. Doi: 10.1590/1414-462X201600010227 
26. Bernardes LE, Vieira EES, Lima LHO, Carvalho GCN, Silva ARV. Risk factors for chronic noncommunicable diseases in university students. Cienc Cuid Saúde. 2015;14(2):1122-8. doi: 10.4025/cienccuidsaude.v14i2.22517

27. Brito BJQ, Gordia AP, Quadros TMB. Estilo de vida de estudantes universitários: estudo de acompanhamento durante os dois primeiros anos do curso de graduação. Medicina (Ribeirão Preto, Online). 2016;49(4):293-302. Doi: 10.11606/issn.2176-7262.v49i4p293-302

28. Lara Flores N, Saldana Balmori Y, Fernandes Vera N, Delgadillo Gutierrez HJ. Salud, calidad de vida y entorno universitario en estudiantes mexicanos de una universidad pública. Hacia Promoc Salud. 2015;20(2):102-17. doi: 10.17151/hpsal.2015.20.2.8

29. Carvalho CA, Fonseca PCA, Barbosa JB, Machado SP, Santos AM, Silva AAM. The association between cardiovascular risk factors and anthropometric obesity indicators in university students in São Luís in the State of Maranhão, Brazil. Ciênc Saúde Colet. 2015;20(2):479-90. doi: 10.1590/1413-81232015202.02342014

30. Fonseca ALP, Zeni LB, Flügel NT, Sakae TM, Remor KVT. Estudo comparativo sobre qualidade do sono entre universitários de uma instituição de ensino do sul catarinense. Arq Catarin Med [Internet]. 2015 [cited 2017 Jul 15];44(4):21-33. Available from: http://www.acm.org.br/acm/ seer/index.php/arquivos/article/view/45

31. Malta DC, Vieira ML, Szwarcwald CL, Caixeta R, Brito SMF, Reis AAC. Smoking Trends among Brazilian population - National Household Survey, 2008 and the National Health Survey, 2013. Rev Bras Epidemiol. 2015;18(Suppl 2):45-56. doi: 10.1590/1980-5497201500060005

32. World Health Organization (WHO). WHO report on the global tobacco epidemic, 2013: Enforcing bans on tobacco advertising, promotion and sponsorship [Internet]. Geneva:WHO; 2013 [cited 2017 Jul 20]. Available from: http://apps.who.int/iris/ bitstream/10665/85380/1/9789241505871_eng.pdf

33. World Health Organization (WHO). Global status report on noncommunicable diseases 2010 [Internet]. Geneva: WHO; 2011 [cited 2017 Jul 20]. Available from: http://www.who.int/nmh/publications/ncd_report_full_en.pdf

34. Ministério da Saúde (BR). Secretaria de Vigilância em Saúde. Vigitel Brasil 2011: Vigilância de Fatores de Risco e Proteção para Doenças Crônicas por Inquérito Telefônico [Internet]. Brasília: Ministério da Saúde; 2012 [cited 2017 Aug 23]. Available from: http://bvsms.saude.gov. br/bvs/publicacoes/vigitel_brasil_2011_fatores_risco_doencas_cronicas.pdf

35. Anacleto TS, Louzada FM, Pereira EF. Ciclo vigília/sono e o transtorno de déficit de atenção/hiperatividade. Rev Paul Pediatr. 2011;29(3):43742. doi: 10.1590/S0103-05822011000300020

36. Araújo MFM, Freitas RWJF, Lima ACS, Pereira DCR, Zanetti ML, Damasceno MMC. Health indicators associated with poor sleep quality among university students. Rev Esc Enferm USP. 2014;48(6):1083-90. doi: 10.1590/S0080-623420140000700017

37. Araújo MFM, Lima ACS, Alencar AMPG, Araújo TM, Fragoso LVC, Damasceno MMC. Sleep quality assessment in college students from Fortaleza-CE. Texto Contexto Enferm. 2013;22(2):352-60. doi: 10.1590/S0104-07072013000200011

38. Carvalho TMCS, Silva Junior II, Siqueira PPS, Almeida JO, Soares AF, Lima AMJ. Qualidade do Sono e Sonolência Diurna Entre Estudantes Universitários de Diferentes Áreas. Rev Neurocienc. 2013;21(3):383-7. doi: 10.4181/RNC.2013.21.854.5p

39. Pascotto AC, Santos BRM. Avaliação da qualidade do sono em estudantes de ciências da saúde. J Health Sci Inst [Internet]. 2013 [cited 2017 Jul 26];31(3):306-10. Available from: https://www.unip.br/presencial/comunicacao/publicacoes/ics/edicoes/2013/03_jul-set/V31_n3_2013_ p306a310.pdf

40. Vasconcelos HCA, Fragoso LVC. Marinho NBP, Araújo MFM, Freitas RWJF, Zanetti ML, et al. Correlation between anthropometric indicators and sleep quality among Brazilian university students. Rev Esc Enferm USP. 2013;47(4):851-8. doi: 10.1590/S0080-623420130000400012

41. Kabrita CS, Hajjar-Muça TA, Duffy JF. Predictors of poor sleep quality among Lebanese university students: association between evening typology, lifestyle behaviors, and sleep habits. Nat Sci Sleep. 2014;6:11-8. doi: 10.2147/NSS.S55538

42. Araújo MAN, Fabi FWP, Bortolon R, Lunardi Filho WD, llha S, Alvarenga MRM. Padrão do sono em estudantes de enfermagem de Universidade Pública Estadual. Rev Cubana Enfermer [Internet]. 2016 [cited 2017 Jul 26];32(2):162-70. Available from: http://scieloprueba. sld.cu/pdf/enf/v32n2/enf03216.pdf

43. Calais SL, Carrara K, Brum MM, Batista K, Yamada JK, Oliveira JRS. Stress entre calouros e veteranos de jornalismo. Estud Psicol (Campinas, Online). 2007;24(1):69-77. doi: 10.1590/S0103-166X2007000100008

44. Lima DR, Luna RCM, Moreira MS, Marteleto MRF, Duran CCG, Dias ETDM. Habilidades Sociais em estudantes de medicina: treinamento para redução de estresse. ConScientiae Saúde. 2016;15(1):30-7. doi: 10.5585/conssaude.v15n1.6047

45. Padovanni RC, Neufeld CB, Maltoni J, Barbosa LNF, Souza WF, Cavalcanti HAF, et al. Vulnerabilidade e bem - estar psicológicos do estudante universitário. Rev Bras Ter Cogn. 2014;10(1):2-10. doi: 10.5935/1808-5687.20140002

46. Lameu JN, Salazar TL, Souza WF. Prevalência de sintomas de stress entre graduandos de uma universidade pública. Psicol Educ. 2016;(42):13-22. doi: 10.5935/2175-3520.20150021

47. Sateia MJ. Update on sleep and psychiatric disorders. Chest. 2009;135(5):1370-9. doi: 10.1378/chest.08-1834 